\title{
Z badań nad budownictwem ludowym Kotliny Rabczańskiej
}

\section{Abstract}

\section{Research on folk Architecture in the Rabka Valley}

The aim of the article is to briefly describe the changes in the form of village buildings in the area of the Rabka Valley from the mid-nineteenth century to the mid-twentieth century (including layouts of villages, plans of farms and houses, constructions of foundations, walls, roofs, floors, ceilings, doors, windows, stoves and decorative elements) and to answer the question whether it is a common heritage of the inhabitants of this area.

Keywords: regional architecture, farm buildings, antique buildings, local heritage, Rabka Valley.

Celem niniejszego artykułu jest krótka charakterystyka budownictwa ludowego okolic Rabki. Teren ten z powodu braku trafniejszych określeń etnograficznych można utożsamić z Kotliną Rabczańską, którą wyróżniają geografowie fizyczni. Co istotne, miejscowości leżące na tym obszarze zostały potraktowane raczej marginesowo w monografiach grup góralskich dotychczas wydanych przez Instytut Antropologii i Etnologii Polskiej Akademii Nauk i Centralny Ośrodek Turystyki Górskiej (Tylkowa 2000; Janicka-Krzywda 2010, 2011, 2013; Ceklarz, Masłowiec 2015). Poniższy opis opiera się na obszernej literaturze przedmiotu ${ }^{1}$; materiałach archiwalnych; fotografiach, mapach i zdjęciach satelitarnych dostępnych $\mathrm{w}$ inter-

${ }^{1}$ Porównane zostały opracowania o różnym zasięgu terytorialnym, przeważnie częściowo zbieżnym z prezentowanym obszarem. Większość odnośników w tekście posiada walor porównawczy. 
necie oraz na własnych wywiadach i obserwacjach autora. Zakres chronologiczny prezentacji zamyka się w ramach lat 1850-1950. Tekst kończy lakoniczna refleksja na temat miejsca chłopskiej zabudowy zagrodowej w ramach dziedzictwa lokalnego.

\section{Kraina geograficzna}

Pojęcie Kotliny Rabczańskiej nie funkcjonuje w potocznym obiegu, choć wydaje się bardzo adekwatne przy naukowym opisie pewnego fragmentu Beskidów Zachodnich. Termin ten wprowadził do fizjografii Jerzy Kondracki w Geografii regionalnej Polski. Ów mezoregion został wyszczególniony dużo później niż graniczące z nim pasma górskie: Gorców (na południowym wschodzie), Beskidu Wyspowego (na północnym wschodzie), Beskidu Makowskiego (na północnym zachodzie) oraz Beskidu Żywieckiego (na południowym zachodzie). W klasyfikacji dziesiętnej obdarzony został numerem 513.50. Obszar ten charakteryzuje się obniżeniem wysokości bezwzględnej do 500-600 m n.p.m. oraz falistym ukształtowaniem powierzchni dna Kotliny. Ponad wierzchowinę wznosi się wyspowo jedynie kilka wzgórz ostańcowych przekraczających 600 m n.p.m., z których najwyższymi są: Grzebień (679 m n.p.m.), Zbójecka Góra (644 m n.p.m.) oraz Bania (607 m n.p.m.). Przestrzeń ta rozdzielona jest pomiędzy dorzecza górnych biegów dwóch ważnych prawostronnych dopływów Wisły: Skawy i Raby. Obydwie rzeki zbliżają się do siebie na odległość $1,5 \mathrm{~km}$ (Kondracki 2000: 329-330). Tereny te zostały zasiedlone przez ludność polską pomiędzy XIV a XVI wiekiem. Wsie tu zakładane należały do dóbr szlacheckich, w przeciwieństwie do obszarów sąsiednich wchodzących w skład królewszczyzn lub własności kościelnej (Rutkowski 2008: $108,110)$. Przez wieki terytorium to było rozdzielone pomiędzy różne jednostki administracyjne, przez co nie było trwale związane z którymś z większych ośrodków miejskich (Gaździcki, Orzeł, Sawina 2016). Obecnie znajduje się na styku czterech powiatów: nowotarskiego, limanowskiego, myślenickiego i suskiego. Zagospodarowaniu tych okolic sprzyjało niewątpliwie dogodne położenie przy szlakach komunikacyjnych. W Skomielnej Białej krzyżuje się trasa zakopiańska (północ-południe) z karpacką (wschód-zachód). Na Zaborni od drogi z Krakowa do Zakopanego odbiega szosa do przejścia granicznego w Chyżnem. W Chabówce natomiast istnieje węzłowa stacja kolejowa, z której od linii łączącej Suchą Beskidzką z Nowym Sączem odchodzi odnoga w stronę Stolicy Tatr. Współcześnie wśród najważniejszych miejscowości położonych na terytorium Kotliny znajdują się: miasto-uzdrowisko Rabka-Zdrój oraz duże wsie: Spytkowice, Skawa i Raba Wyżna. 


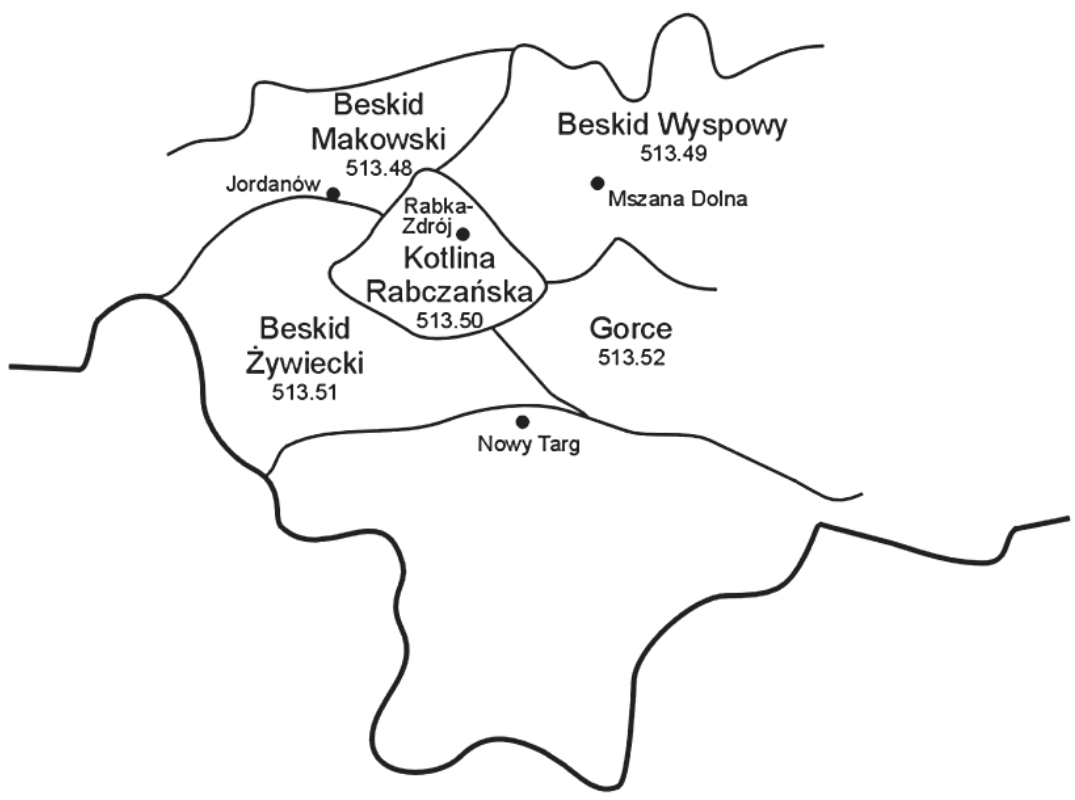

Ilustracja 1. Położenie Kotliny Rabczańskiej na tle sąsiednich mezoregionów (oprac. autor)

\section{Kraina etnograficzna}

Kotlina Rabczańska nie stanowi jednolitej jednostki zróżnicowania etnograficznego kraju. Znajduje się ona na styku kilku zwyczajowo wyróżnianych subkultur regionalnych. W pierwszym szczegółowym studium na temat podziałów wewnętrznych góralszczyzny, którym było niewątpliwie opracowanie Rzut oka na pótnocne stoki Karpat z 1851 roku, Wincenty Pol, przyjmując najwidoczniej klucz determinizmu fizycznogeograficznego, przecina interesujący nas teren wzdłuż działu wodnego, lokalizując $\mathrm{w}$ dolinie Skawy grupę Babiogórców, natomiast w dolinie Raby grupę Zagórzan (1851: 121-122). Zaproponowana przez uczonego klasyfikacja grup góralskich była następnie wielokrotnie powtarzana przez innych autorów. Józef Konopka w Encyklopedii rolnictwa z 1874 roku, nawiązując do ustaleń poety-geografa, wprowadza dodatkowy podział górali zagórzańskich na Porębian i Rabczan, przy czym za tych ostatnich uznaje mieszkańców doliny górnej Raby (1874: 813, 824-826). Nie wszyscy ówcześni ludoznawcy akceptowali jednak tę terminologię. Izydor Kopernicki - aktywny zbieracz folkloru z okolic Rabki - nazywa mieszkańców tych terenów Góralami Bieskidowymi lub po prostu Rabczańskimi (1888a: 117-120; 1888b: 230-231). Jeszcze inaczej postępuje Seweryn Udziela w krótkim, lecz ważnym opracowaniu Etnograficzne ugrupowa- 
nie i rozgraniczenie rodów górali polskich z 1918 roku. Według mapy sporządzonej przez badacza interesujące nas obszary leżą w zasięgu grupy Kliszczaków (1918: 82). Pogląd ten dominuje w kolejnych próbach regionalizacji etnograficznej Karpat podejmowanych w pierwszej połowie XX wieku. Po II wojnie światowej zaczęło utrwalać się przeświadczenie, że tereny położne na północ od linii Gorców i Pasma Podhalańskiego należy uznać za część Podhala. Jak zauważa między innymi Janusz Kamocki w Zarysie grup etnograficznych $w$ Polsce, kultura ludowa okolic Rabki uległa z czasem podhalanizacji. Autor proponuje zatem wyróżnienie dla tego obszaru odrębnej podgrupy (1992: 111).

\section{Rozplanowanie wsi}

Przez wieki na opisywanym obszarze dominował wynikający z osadnictwa łanowo-leśnego układ łańcuchówek przysiółkowych (Reinfuss 1970: 25). Kilkudomowe osiedla nazywane w zależności od swej wielkości rolami lub zarębkami rozlokowane były wzdłuż głównej osi, którą stanowiła rzeka wraz z wijącą się wokół niej główną drogą i obszarem wspólnego użytkowania, na którym z czasem wydzielane były zagrody, czyli mniejsze działki zasiedlane przez rzemieślników i chłopów małorolnych. Nazwy własne przysiółków powstawały przeważnie od nazwisk właścicieli pierwszych gospodarstw. Lokalna toponimia kształtowała się zazwyczaj przez dodanie do nazwiska przyrostka -ówka (np. Sordylówka w Spytkowicach, Jardusiówka w Rabie Wyżnej czy Bachulówka Wyżnia w Sieniawie), rzadziej za pomocą końcówki -owa (np. Otrębowa w Skomielnej Białej) albo przyimków do (np. Do Zająca w Rokicinach) lub $u$ (np. U Gila w Rabce-Słonem). Obok nich występowały jednak także inne nazwy miejscowe (np. Granice w Chabówce, Pańskie w Skawie, Bór w Bielance, Rola w Rdzawce). Tradycyjne podziały miejscowości w dużej mierze zachowały się do dzisiaj, pomimo że współczesna zabudowa zatarła wcześniej łatwo zauważalne granice między nimi (TERYT). Obecnie większe wsie (Spytkowice, Skawa, Raba Wyżna, Skomielna Biała) nie posiadają już jednoliniowego planu przestrzennego. Miasto Rabka-Zdrój zupełnie zatraciło pierwotny układ ruralistyczny, który na mapach katastralnych z połowy XIX wieku, a więc jeszcze przed budową linii kolejowej i uruchomieniem uzdrowiska, był całkiem klarowny (ANK). Aktualnie na podstawie topografii terenu trudno jest nawet ustalić dawny przebieg głównej drogi wiejskiej.

\section{Rozplanowanie zagrody}

W niższych partiach wsi większość domów była stawiana ścianą frontową w kierunku południa, i to niezależnie od przebiegu drogi wiejskiej. Orientacja zabudowań rozlokowanych na stokach była w większym stopniu dostosowana 
do poziomic (Leszczycki 1990: 51). Najbardziej archaiczną formą zabudowy siedliska była zagroda jednobudynkowa, w której pomieszczenia inwentarskie zostały zespolone $\mathrm{z}$ chałupą $\mathrm{w}$ linii parteru, natomiast poddasze pełniło funkcję magazynową. Tego typu obiekty przeważały $\mathrm{w}$ dziewiętnastowiecznym krajobrazie (Grabski 2015: 155).

Naturalną koleją rzeczy rozwój gospodarki chłopskiej skutkował zwiększeniem popytu na przestrzeń. W warunkach Kotliny Rabczańskiej, gdzie powierzchnia przydomowego placu ograniczona była górskim lub przynajmniej pagórkowatym ukształtowaniem terenu, nie było możliwości dowolnego rozciągania zagrody jednodachowej wzdłuż (Leszczycki 1932b: 113). W konsekwencji część gospodarcza musiała zostać odseparowana od części mieszkalnej poprzez wystawienie zupełnie oddzielnych zabudowań albo przez przeniesienie do bocznego skrzydła.

W pierwszym przypadku obok chałupy wystawiano stodołę lub budynek łączący stajnię, boisko i sąsiek pod jednym dachem. Ustawienie domostwa i tak zwanej szopy względem siebie mogło przybierać różne konfiguracje $\mathrm{w}$ zależności od warunków terenowych. Najczęściej zaplecze inwentarsko-magazynowe stawiano mniej więcej równolegle za wzdłużną ścianą chaty. Niewiele rzadsze były ułożenie prostopadłe lub pod kątem zbliżonym do $45^{\circ}$. Trochę rzadszy był rozkład szeregowy, w którym obydwie budowle zbliżały się do siebie ścianami szczytowymi. Zagrody dwubudynkowe były już dość popularne pod koniec XIX i na początku XX wieku. Obejścia złożone z trzech wolnostojących elementów występowały w tych okolicach raczej sporadycznie. Nie oznacza to jednak, że były tu zjawiskiem zupełnie późnym. Istnienie gospodarstw wielobudynkowych w Spytkowicach już w XVII i XVIII wieku potwierdzają źródła historyczne (Czajkowski 1988, tab. I, Ia). Przypuszcza się jednak, że należały one wtenczas tylko do najbogatszych kmieci.

Druga taktyka architektoniczna zmierzała do wytworzenia jednej budowli o kształcie wykraczającym poza zarys prostokąta. Pierwszym jej etapem była klasyczna zagroda l-kształtna (kątowa), kojarzona przeważnie z Podhalem, a pojawiająca się na północ od Gorców i Beskidu Orawsko-Podhalańskiego już w pierwszym ćwierćwieczu XX stulecia. Występowała ona w kilku wariantach. W zależności od profilu terenu ramię gospodarcze ograniczało przestrzeń podwórza od wschodu lub zachodu. Mogło też być wysunięte przed elewację chałupy lub za nią w głąb siedliska (Baniowska, Jagiełła 2000: 185-186). Ten brak konsekwencji stanowi pewne przeciwieństwo w stosunku do podobnych dwuskrzydłowych zagród zlokalizowanych w ulicówkach na Podtatrzu. Tam bowiem zaplecze gospodarskie znacznie częściej stawiane było w taki sposób, aby chroniło dziedziniec przed silnymi podmuchami wiatrów wiejących od strony otwartych przestrzeni pól uprawnych, co dobrze widać choćby na przykładzie Chochołowa czy Białego Dunajca. Rozbudowa zagrody prostopadłej o trzecie skrzydło doprowadziła do powstania zabudowań na rzucie podkowy. W programie u-kształtnym najczęściej główna oficyna gospodarcza znajdowała się naprzeciw tylnej ściany li- 
cowej domostwa. Mniejszy gabarytowo łącznik pełnił przeważnie funkcje schówkowe. To ustawienie jest dość często spotykane w zabudowie z drugiego ćwierćwiecza XX stulecia (Leszczycki 1990: 89). Ostatnim etapem rozwoju zagrody było jej całkowite, czterostronne zamknięcie. Okólniki szczególnie chętnie budowane były w Skomielnej Białej. Obiekty takie powstawały zwłaszcza w okresie międzywojennym i w latach powojennych (Cieśla-Reinfussowa 1970: 32).

\section{Rozplanowanie wnętrza chałupy}

Analogiczna, chronologicznie postępująca ewolucja od układów prostszych do bardziej złożonych zauważalna jest w przypadku wnętrz. Najstarszym zanotowanym rodzajem siedziby mieszkalnej jest chata jednoizbowa $\mathrm{z}$ bocznie dostawioną sienią. Zapewne większość tego typu obiektów była szerokofrontowa, jak niemal wszystkie później występujące odmiany chałup. Tak małe domki były zbyt ciasne, aby pomieścić członków wielodzietnych rodzin wiejskich. Na początku XX wieku należały już do rozwiązań przestarzałych i charakteryzowały uboższą ludność (Czajkowski 1976: 56).

Rozwój planu przestrzennego zaczynał się od dostawienia komory. Poprzez dodanie urządzeń ogrzewczych oraz zaopatrzenie w okna pomieszczenie magazynowe zamieniało się w białą izbę, nazywaną przeważnie świetlicą (świetnicą) dla odróżnienia od czarnej izby, która określana była jako piekarnia (Grabski 2013: 145; Cieśla-Reinfussowa 1970: 40). Usytuowanie drugiego wnętrza mieszkalnego względem sieni definiowało program symetryczny lub asymetryczny. Jednotraktowa wersja chałupy z centralną sienią i dwiema izbami po jej bokach została odnotowana już w XVII wieku w Spytkowicach (Czajkowski 1988, tab. IV). Stanowiła ona jednak najpopularniejszy do połowy XX stulecia wzór architektoniczny w tym rejonie. $\mathrm{W}$ okresie międzywojennym i powojennym, gdy drzwi zewnętrzne były już przeważnie osłaniane gankami, powszechna stała się zamiana środkowego korytarzyka na kuchnie przy przeznaczeniu izb bocznych pod sypialnie (Orzeł 2014: 39). W pierwszej połowie XX wieku zamożniejsi gospodarze stawiali już symetryczne domy dwutraktowe złożone z sieni i czterech izb (Leszczycki 1990: 109). Rozkład ten został następnie zaakceptowany i bywał przekształcany w powojennym murowanym budownictwie mieszkaniowym.

Drugi typ układu funkcjonalnego był charakterystyczny zwłaszcza dla miejscowości leżących we wschodniej części Kotliny Rabczańskiej w bezpośrednim sąsiedztwie Orawy (Reinfuss 1950: 36-37). W rozplanowaniu asymetrycznym sień i dwie izby znajdowały się w amfiladzie. Rzeczą niezmienną było, że pierwsza z izb posiadała charakter kuchni, zaś następna pokoju. Rozwój przestrzenny w tym przypadku następował przede wszystkim wzdłuż. Najczęściej trzecia izba była wystawiana po przeciwnej stronie sieni. Zarówno właściwe dwuizbowe chałupy asymetryczne, jak i trójizbowe (pośrednie pomiędzy planem symetrycznym 
i asymetrycznym) powstawały licznie już od połowy XIX wieku (Cieśla-Reinfussowa 1970: 32-33, 37). Zaprzestano ich wznoszenia we wczesnych latach powojennych. O wiele rzadziej budowano obiekty złożone $\mathrm{z}$ trzech izb ustawionych obok siebie (Leszczycki 1990: 108). Dwutraktowe typy domów asymetrycznych pojawiły się natomiast $\mathrm{w}$ ostatnim etapie masowego budownictwa drewnianego, który przypadł w tych okolicach na lata 40. i 50. XX wieku (tamże: 109).

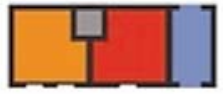

Sieniawa, $1887 \mathrm{r}$.

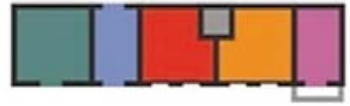

Raba Wyżna, 1889 r.

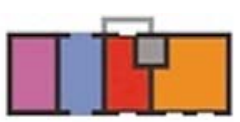

Rokiciny Podhalańskie, przełom XIX i XX w.

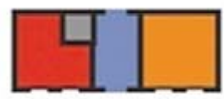

Ponice, lata 20. 30. XX w.
Skawa, Rabka początek XX w.

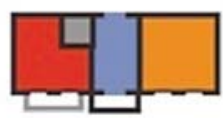

przełom XIX i XX w.
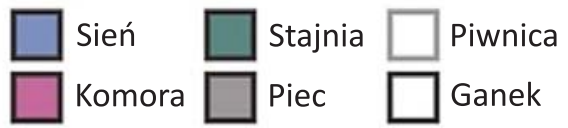
- Drzwi zewnętrzne - Okno

Ilustracja 2. Przykłady rozplanowań chałup (oprac. autor)

Na marginesie rozważań o rzucie parteru należy wspomnieć o pomieszczeniach znajdujących się na innych poziomach. Piwnice, o ile nie stanowiły oddzielnych zabudowań lub nie znajdowały się przy stodołach, były zlokalizowane pod jedną z izb, ewentualnie obok ściany szczytowej chałupy. Dostęp do nich przeważnie był możliwy jednie od zewnątrz (Grabski 2011: 130). Pojawienie się innych pomieszczeń w przyziemiu, najczęściej warsztatów, datuje się na drugie ćwierćwiecze XX stulecia. Strych pełnił oryginalnie funkcje lamusa. Na obszarze Kotliny Rabczańskiej w zagrodach chłopskich raczej nie budowano samodzielnych spichlerzy, choć mogłoby tak wynikać z zakresu ich występowania przedstawionego w Polskim atlasie etnograficznym (Gajek 1958, mapa 14). Ich funkcję pełniły wyżki. Obiekty takie występowały na znacznie szerszym terytorium niż powszechnie kojarzona z nimi Orawa. Istnienie tego elementu w Spytkowicach w XVII wieku potwierdzają dane historyczne (Czajkowski 1988, tab. IV). W drugiej połowie XX wieku był już traktowany jako relikt przeszłości, ale można było go dostrzec jeszcze w Rabie Wyżnej i Spytkowicach, a pamiętano go jeszcze w Skawie i Skomielnej Białej (Cieśla-Reinfussowa 1966: 118). Na białych i zielonych kartach wykona- 


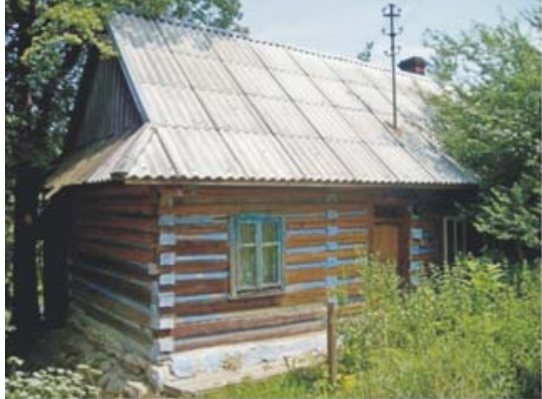

Sieniawa, druga połowa XIX w.

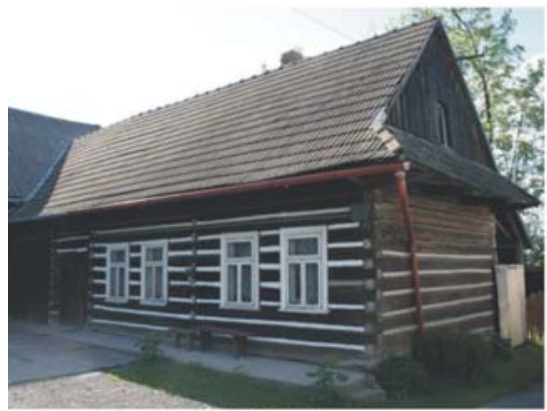

Skawa, przełom XIX i XX w.

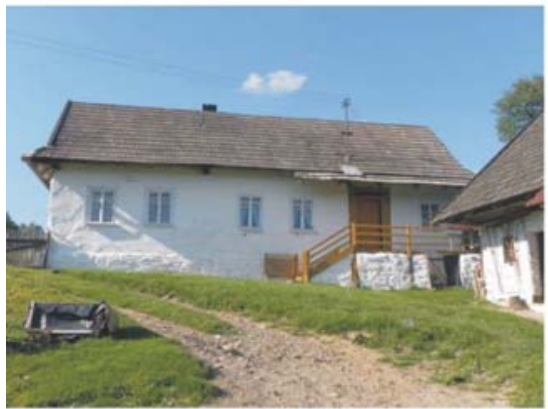

Rokiciny Podhalańskie, 1904 r.

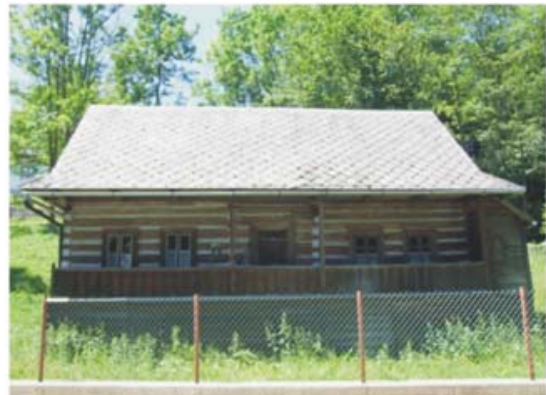

Rdzawka, początek XX w.

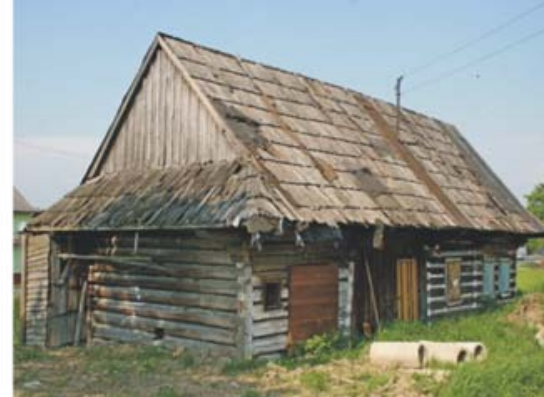

Spytkowice, przełom XIX i XX w.

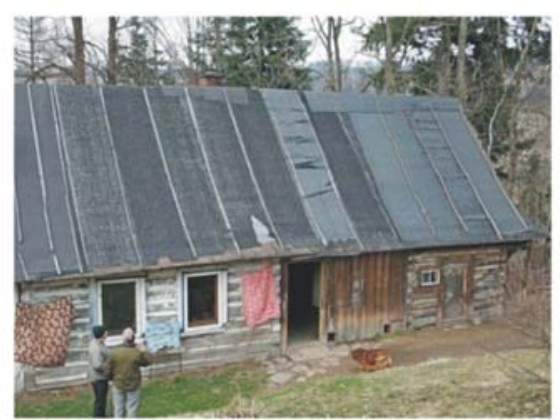

Raba Wyżna, przełom XIX i XX w.

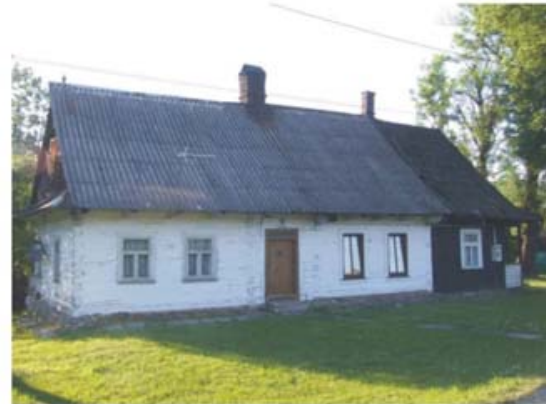

Rabka, ok. 1906 r.

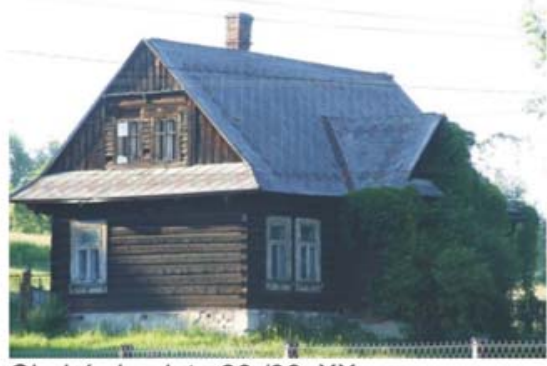

Chabówka, lata 20./30. XX w.

Ilustracja 3. Przykłady zabytkowych chałup (fot. autor) 
nych w latach 60. i 70. XX wieku dla Spytkowic można zaobserwować jeszcze chałupy z charakterystycznymi „orawskimi” przedwyżcami (WUOZK).

Od momentu uruchomienia pierwszego zakładu kąpielowego w Rabce w 1864 roku w okolice zaczęli napływać kuracjusze (Janowiec, Trybowska 2001: 6). Wzrastające $z$ biegiem lat zapotrzebowanie na miejsca noclegowe przyczyniło się do znacznej ingerencji w miejscowy krajobraz. Okazji łatwego zarobku nie odpuszczali chłopi, ustępując na okres letni swe izby gościom. Gdy te okazywały się zbyt małe, letników zaczęto kwaterować w pomieszczeniach urządzanych na poddaszach, wpierw tylko w ryzalitach nad gankami, następnie na całej szerokości domów. Tym sposobem z tradycyjnego budownictwa ludowego wykształciła się na poły regionalna architektura willowa, reprezentowana najliczniej w uzdrowiskowej części Rabki i na Słonem. Równocześnie jednak obok niej pojawiała się zabudowa pensjonatowa zupełnie nie nawiązująca do lokalnej stylistyki (Leszczycki 1990: 109; Klimaszewska 1931: 196).

\section{Konstrukcja fundamentów}

Najstarszym typem fundamentu, którego można dopatrzeć się jeszcze dziś w starszych obiektach, były pecki kamienne podkładane pod narożniki i łączenia ścian budowli. Przestrzeń pomiędzy punktami podparcia była luźno wypełniana kamieniami lub zakrywana deskami (Grabski 2015: 156). Pierwotnie chałupy były stawiane wyłącznie na wyrównanym gruncie. Większość dziewiętnastowiecznych budynków posiadała bardzo niskie podmurowanie. Ze względu na duży nacisk zrębu na podłoże nie wykonywano wysokich pecek w formie słupów. Domy i zabudowania gospodarcze usytuowane na bardziej stromych stokach zaczęły upowszechniać się pod koniec XIX wieku, kiedy to z powodu przyrostu ludności dogodniejsza przestrzeń siedliskowa była już zajęta. Taka lokalizacja wymagała zastosowania wysokich, pełnych fundamentów. Podmurówkę przeważnie wznoszono z nieobrobionego piaskowca (Leszczycki 1932b: 116). W jej najwyższym miejscu bardzo często umieszczano wejście do znajdującej się pod skrajną izbą piwniczki. W okresie międzywojennym popularna stała się podmurówka kamienna zwieńczona górnym wątkiem ceglanym. Po 1945 roku powszechne stało się tynkowanie i malowanie fundamentów, nierzadko udekorowane boniowaniem. W pierwszych latach po II wojnie światowej na szerszą skalę zaczęto używać betonu (Orzeł 2014: 61-62).

\section{Konstrukcja ścian}

Początkowo ściany chałup były budowane wyłącznie z okrąglaków sosnowych i jodłowych. Zrąb budynku układano z kilku bierwion łączonych w narożach na węgieł prosty, zbliżony nieco do rybiego ogona. Stabilność konstrukcji wień- 
cowej zwiększały teble spinające sąsiadujące belki. Szczeliny pomiędzy nimi upychano mchem leśnym, trawami lub słomą i zalepiano gliną (Grabski 2013: 144). Ściany takie pozostawiano nieobielone.

Najprawdopodobniej na przełomie XIX i XX wieku zaczęły upowszechniać się różne innowacje. Do budulca drzewnego włączono świerczynę. Pełne bierwiona zaczęto zastępować płazami i kanciakami. Ostatki belek wyrównywano do linii płaszczyzny ściennej. Utrwaliła się także występująca w wielu wariantach praktyka bielenia fasad wapnem. Część chałup malowano całkowicie na modłę znaną z podkrakowskich wsi (Reinfuss 1949: 200). Większość jednak posiadała kolorystyczne wyróżnienie wyłącznie spoin, samych węgłów lub jednocześnie obydwu tych elementów (Leszczycki 1990: 135). Sporadycznie nie pokrywano całych ostatków, a jedynie wykonywano na nich znak $X$. W przypadku zagród jednodachowych nierzadko zdarzało się, że część mieszkalna posiadała ściany całkiem białe, natomiast część gospodarcza - w pasy. Bardzo często do wapna dodawano niebieskiego pigmentu, przez co malowane powierzchnie przybierały odcień błękitny (Reinfuss 1949: 201).

W latach międzywojennych przy węgłowaniu płazów zaczęto stosować również bardziej skomplikowane i mocniejsze zamki podhalańskie (Baniowska 2000: 176). Tego typu rozwiązanie widoczne jest zwłaszcza w miejscowościach leżących w pobliżu Kotliny Nowotarskiej: w Rdzawce, Sieniawie i Bielance. Bardzo możliwe, że konstrukcje te wznosili cieśle z głębi Podhala. Uszczelnianie wolnych przestrzeni pomiędzy bierwionami udoskonalono warkoczami $z$ wełny drzewnej. Tuż przed wybuchem wojny zaczęto ściany szalować, tynkować oraz malować farbą olejną (Leszczycki 1990: 135-136). Wszystkie te czynności wykonywano już na masową skalę w latach 40. i 50., kiedy to surowe czy nawet bielone zręby zaczęły być utożsamiane z zaściankiem.

Drugie ćwierćwiecze XX stulecia było także okresem pojawienia się domów wznoszonych z cegły. Budulec ten był produkowany z miejscowych pokładów iłu (Orzeł 2014: 51). Najwięcej tego typu obiektów powstało w Rabce, Chabówce, Skomielnej Białej, Skawie, Rokicinach Podhalańskich i Rabie Wyżnej. Do dziś zachowało się kilka budynków posiadających boniowane pilastry podkreślające podział elewacji. W 1942 roku w Skomielnej Białej podjęto eksperyment polegający na wznoszeniu ścian z bitej gliny, jednak technika ta nie zyskała szerszej aprobaty (Miśkowiec 2015: 299). Materiały ognioodporne zdominowały lokalną architekturę po wojnie.

\section{Konstrukcja dachów}

W krajobrazie Kotliny Rabczańskiej z połowy XIX wieku najprawdopodobniej przeważały dachy czterospadowe, konstrukcji krokwiowo-zrębowej, pokryte gontem, dranicami lub słomą. Bardzo często różne materiały kryjące występowały na 
jednej połaci (Leszczycki 1933: 210). Bryła czterospadowa najdłużej utrzymała się w Spytkowicach ze względu na występujące tam przedwyżce (Zawiliński 1931: 172). Tam też jeszcze w okresie powojennym istniało wiele domów o dachach naczółkowo-przyczółkowych (WUOZK).

$\mathrm{Na}$ początku następnego stulecia upowszechnił się już dach dwuspadowy, przyczółkowy, o kącie łączenia krokwi w kalenicy dochodzącym do $75^{\circ}$ (Grabski 2010: 107). Coraz rzadziej do krycia używano słomy. Miejsce strzechy z czasem zastąpiły inne materiały: papa, eternit $\mathrm{w}$ formie płytek, blacha, zakładkowa dachówka ceramiczna i cementowa (Leszczycki 1990: 139-144). Ostatni z wymienionych budulców cieszył się sporym wzięciem zwłaszcza w latach powojennych, kiedy to na masową skalę zaczęły powstawać w okolicy małe pracownie betoniarskie (Orzeł 2014: 53). W tym czasie dachy starych budynków zaczęto także pokrywać falistym eternitem i giętą blachą. Zwiększenie szerokości budynków oraz zastosowanie ciężkich materiałów ogniotrwałych zrodziło potrzebę wzmocnienia więźb dachowych ścianami stolcowymi.

\section{Konstrukcja płaszczyzn poziomych}

W XIX wieku sporo chałup posiadało jeszcze klepisko. Na początku XX wieku upowszechniła się podłoga deskowana. Techniką wykonania naśladowała powałę. W obydwu przypadkach na wierzch stragarzy biegnących poprzecznie względem ścian licowych przybijano odeskowanie. Jeszcze w okresie międzywojennym stropy izb były wzmacniane belkami podciągowymi. Sosręby przeważnie były zdobione. W centralnym miejscu umieszczano rozetę cyrklową. Po jej bokach znajdowały się wyryte nazwiska fundatorów, daty ukończenia budowy, sentencje religijne lub motywy roślinne (Cieśla-Reinfussowa 1970: 52). Już przed II wojną światową zaprzestano stosowania dużych tragarzy, a istniejące często usuwano. Wraz z pojawieniem się tynków wewnątrz $\mathrm{w}$ domach deskowe powały zaczęto zastępować gładkimi sufitami.

\section{Konstrukcja otworów ściennych}

Otwory znajdowały się przede wszystkim w skierowanych ku południowi ścianach frontowych chałup. Izby oświetlane były przeważnie przez dwa okienka. Bardzo często w ścianie tylnej istniały tylko drzwi na podwórze, natomiast ściany szczytowe w ogóle nie posiadały żadnych wycięć. Potrzeba docieplenia wnętrza powodowała, że płaszczyzny te były obudowywane dodatkowymi pomieszczeniami wykonanymi w konstrukcji szkieletowej, służącymi za drewutnie lub schowki na narzędzia rolnicze (Orzeł 2014: 42). Z tego powodu drzwi wejściowe były niższe od wysokości przeciętnego dorosłego mężczyzny, a okna małe, o kształcie 
zbliżonym do kwadratu. Jeszcze w pierwszym ćwierćwieczu XX stulecia do domostw wchodziło się najczęściej poprzez odrzwia wzmocnione tak zwanymi pieskami (Grabski 2015: 157). Czteroszybkowe okienka były zwieńczone trójkątnymi nadokiennikami (Grabski 2011: 130). Po I wojnie światowej wraz z polepszeniem warunków izolacyjnych budowli powiększono otwory ścienne. Deskowo-spongowe skrzydła drzwiowe zastąpiły płycinowe. Pojawiły się także okna rozwierne o trzech szybkach w skrzydle oraz odchylne nadślemienia. Od lat 40. zaczęto powszechnie montować szerokie okna trójdzielne (Cieśla-Reinfussowa 1970: 46).

\section{Konstrukcja pieców}

Bardzo możliwe, że w drugiej połowie XIX wieku na terenie Kotliny Rabczańskiej stawiano jeszcze chaty kurne w ścisłym tego słowa znaczeniu. Chałupy pozbawione komina, w których dym był odprowadzany znad pieca na poddasze, a stamtąd przez dymniki na zewnątrz, istniały jeszcze w latach 30. XX wieku, choć nie były liczne (Leszczycki 1990: 145). Pierwsze urządzenia paleniskowe były sporych wymiarów i zajmowały około jednej czwartej powierzchni izby czarnej/piekarni. Wznoszone były z kamienia i oblepiane gliną. Początkowo sąsiednie pomieszczenie było ogrzewane wypuszczonym trzonem pieca piekarskiego. $Z$ czasem w izbie białej/świetlicy zaczęto wznosić samodzielne urządzenia ogniowe, podłączone jednak do wspólnego przewodu kominowego (Orzeł 2014: 87-90). Na przełomie XIX i XX wieku z pewnością instalowano już blachy oraz kapy w piecach kuchennych (Syrokomla-Syrokomski 1969: 57-58). W okresie międzywojennym pojawiły się natomiast piece kaflowe.

\section{Zdobnictwo}

Budownictwo Kotliny Rabczańskiej nie charakteryzowało się wysoko rozwiniętą sztuką snycerską. Prócz wspomnianych wcześniej detali umieszczonych na sosrębie wnętrze nie było specjalnie dekorowane. Podnosić estetykę pomieszczeń mogło zatem wyłącznie umeblowanie. Nieco więcej elementów zdobiących znajdowało się na zewnątrz. Już na początku XX wieku powszechnie deskowano szczyty w układzie jodełki lub umieszczano w nich motyw słoneczka (Baniowska 2000: 183). Także w tym okresie wypusty bierwion zaczęły być profilowane, początkowo przez zaokrąglenie krawędzi, a z czasem coraz fantazyjniej modelowane na kształt fali. W dużej mierze były to innowacje zaczerpnięte ze Skalnego Podhala (Flizak 1948: 40). Duży wpływ w zakresie użycia tych form miała zapewne zakopiańszczyzna witkiewiczowska (Baniowska 2000: 211). Innym źródłem inspiracji dla miejscowych budowniczych był styl szwajcarski, w którym wznoszono zabudowania uzdrowiskowe Rabki (Grabski 2015: 165). Zdobnictwo to uwydatniło się 
zwłaszcza przy deskowaniu ganków słupkowych (Cieśla-Reinfussowa 1970: 55). W okresie międzywojennym, gdy ganki zabudowywano, pojawiła się jeszcze jedna możliwość upiększania domostwa. Szczeblinki dużych okien często układano w ornamenty geometryczne (Orzeł 2014: 86).

\section{Budownictwo ludowe - dziedzictwo regionu?}

Fenomen budownictwa ludowego definitywnie należy do przeszłości. Ze względu na realizowane cele, zaplecze techniczno-materiałowe, odniesienie do czynników fizycznogeograficznych oraz ukonstytuowanie w określonym środowisku społeczno-kulturowym nie jest i nie może być współcześnie ani kontynuowane, ani odrodzone. In situ odnajdziemy wyłącznie jego relikty, i to poddane wpływowi ostatnich dekad. Obiekty te są raczej źródłami, które należy interpretować w szerszym kontekście procesów historycznych, a nie „wehikułami czasu”, które przez swą niezmienność przenoszą obserwatora w minioną epokę. Wspomnieć należy, że na opisywanym terenie najciekawsze zabytki tej architektury możemy dziś zaobserwować w Sieniawie, Skawie, Skomielnej Białej, Spytkowicach, Rabie Wyżnej, Rdzawce i Rabce-Zarytem.

Już zaprezentowany w niniejszym artykule opis podstawowych form budownictwa ludowego Kotliny Rabczańskiej, pomimo swego holistycznego charakteru, nadmienia ewolucję temporalną form budowlanych oraz ich zróżnicowanie przestrzenne. Zasięg żadnego z zaprezentowanych zjawisk nie ograniczał się jednak wyłącznie do zakreślonego terytorium. Co więcej, da się również zaobserwować mnogość różnorakich wariantów występujących równolegle obok siebie. Działanie polegające na wyróżnieniu stylistyki, która na podstawie obiektywistycznej metodologii miałaby szczególnie wyróżniać zabudowę wiejską Kotliny Rabczańskiej, siłą rzeczy musi być skazane na niepowodzenie.

Regionalizacja budownictwa ludowego zakłada tworzenie modeli będących syntezą rozmaitych subiektywnie dobranych elementów, które nie odzwierciedlają w sposób statystyczny przeciętnego wyglądu miejscowości (Gładyszowa 1976: 280). Jest ona zatem rodzajem stereotypizacji. Jeżeli możliwe jest kultywowanie dziedzictwa historycznej, chłopskiej zabudowy zagrodowej, to tylko przy założeniu, że konstrukt ten zostanie użyty jako inspiracja do projektowania nowych wzorców architektonicznych. Tu jednak trzeba rozdzielić kwalifikacje etnografów i innych badaczy, których zadaniem jest wydobycie i rzetelne omówienie zastanych form budownictwa ludowego; animatorów, którzy będą je wartościować i promować, oraz projektantów, którzy je wykorzystają w nowych kontekstach architektonicznych i krajobrazowych. Taki sposób pielęgnacji dziedzictwa może być w przyszłości tematem oddzielnych studiów etnograficznych. 


\section{Bibliografia}

Bachmann A.

1929 Dach $w$ słowiańskim budownictwie ludowym, Lwów.

Baniowska E., Jagiełła K.

2000 Architektura ludowa, w: Podhale: Tradycja we współczesnej kulturze wsi, red.

D. Tylkowa, Kraków, s. 171-213.

Beiersdorf Z., Krasnowolski B.

1982 Rozwój przestrzenny i architektura Rabki, „Teka Komisji Urbanistyki i Architektury", t. 16, s. 125-136.

Bogdanowski J.

1994 Regionalizm a krajobraz, w: Regiony kulturowe a nowa regionalizacja kraju, red.

J. Damrosz, M. Konopka, Ciechanów.

Bogusz W.

1999 Projektowanie architektoniczne i budownictwo regionalne, Warszawa.

Bujak J.

1961 Zarys kultury ludowej okolic Rabki, Rabka.

Ceklarz K.

2012 Babcyne korole. Z etnografii południowej Polski, Kraków.

Ceklarz K., Masłowiec J. (red.)

2015 Kultura ludowa górali kliszczackich, Kraków.

Cieśla-Reinfussowa Z.

1966 Chałupa z wyżka w Myślenickiem, „Polska Sztuka Ludowa”, t. 20, z. 2, s. 113-118. 1967 Zagadnienie chałupy z wyżka w ludowym budownictwie Małopolski, „Materiały Muzeum Budownictwa Ludowego w Sanoku”, nr 5, s. 17-19.

1970 Budownictwo ludowe, w: Monografia powiatu myślenickiego, red. R. Reinfuss, M. Rydlowa, t. 2, Kultura ludowa, Kraków, s. 29-60.

Ciołek G.

1984 Regionalizm $w$ budownictwie wiejskim $w$ Polsce (przedruk pracy archiwalnej), t. 1, Kraków.

Czajkowski J.

1976 Budownictwo wiejskie w Krakowskiem, „Materiały Muzeum Budownictwa Ludowego w Sanoku", nr 22, s. 49-123.

1980a Regionalizacja budownictwa mieszkalnego na północnych stokach Karpat, „Materiały Muzeum Budownictwa Ludowego w Sanoku", nr 26, s. 5-14.

1980b Stan badań nad wiejskim budownictwem w polskich Karpatach, „Materiały Muzeum Budownictwa Ludowego w Sanoku", nr 26, s. 14-41.

1988 Budownictwo ludowe w Karpatach w XVI-XIX wieku. Źródła, komentarze, Sanok. 1993 Budownictwo ludowe w polskich Karpatach w XVI-XX wieku, „Materiały Budownictwa Ludowego w Sanoku", nr 31, s. 5-29.

Czerwiński T.

2006 Budownictwo ludowe w Polsce, Warszawa.

Dobrowolska M.

1948 Dynamika krajobrazu kulturalnego, „Przegląd Geograficzny”, t. 21, z. 3-4, s. 151203.

Flizak S.

1948 Przemiany w kulturze materialnej Zagórzan, „Orli Lot”, nr 3, s. 37-42. 
Gajek J. (red.)

1958 Polski atlas etnograficzny, z. próbny, mapy 1-17, Wrocław.

1964 Polski atlas etnograficzny, z. 1, mapy 1-57, Warszawa.

1965 Polski atlas etnograficzny, z. 2, mapy 58-129, Warszawa.

1967 Polski atlas etnograficzny, z. 3, mapy 130-190, Warszawa.

1971 Polski atlas etnograficzny, z. 4, mapy 191-250, Warszawa.

1974 Polski atlas etnograficzny, z. 5, mapy 251-304, Warszawa.

1981 Polski atlas etnograficzny, z. 6, mapy 305-355, Warszawa.

Gaździcki M., Orzeł T., Sawina A.

2016 Historia administracji terytorialnej w Dolinie Górnej Raby, „Almanach Nowotarski”, nr 20, s. 149-166.

Gładyszowa M.

1976 Budownictwo, w: Etnografia Polski. Przemiany kultury ludowej, red. M. Biernacka, B. Kopczyńska-Jaworska, A. Kutrzeba-Pojnarowa, W. Paprocka, t. 1, Wrocław, s. $279-327$.

Grabski M.

2010 Budownictwo ludowe, w: Kultura ludowa górali babiogórskich, red. U. Janicka-Krzywda, Kraków, s. 97-122.

2011 Tradycyjne budownictwo ludowe, w: Kultura ludowa górali orawskich, red. U. Janicka-Krzywda, Kraków, s. 113-138.

2013 Budownictwo drewniane, w: Kultura ludowa górali zagórzańskich, red. U. Janicka-Krzywda, Kraków, s. 135-150.

2015 Budownictwo drewniane, w: Kultura ludowa górali kliszczackich, red. K. Ceklarz, J. Masłowiec, Kraków, s. 145-170.

Holewiński M.

1992 Mlekodajówka, „Wiadomości Rabczańskie”, nr 26, s. 7.

Janicka-Krzywda U. (red.)

2010 Kultura ludowa górali babiogórskich, Kraków.

2011 Kultura ludowa górali orawskich, Kraków.

2013 Kultura ludowa górali zagórzańskich, Kraków.

Janowiec J., Trybowska E.

2001, Rabka na starej fotografii, Rabka-Zdrój.

Kamocki J.

1992 Zarys grup etnograficznych w Polsce, „Annales Universitatis Mariae Curie-Skłodowska: Sectio F", t. 46/47, s. 103-131.

Klein S. (red.)

2013 Między starym a nowym: tradycyjne budownictwo ludowe a współczesna architektura wiejska, Wdzydze.

Klimaszewska J.

1931 Rabka, „Wierchy”, t. 16, nr 11, s. 194-201.

1938 Dach chaty w Polsce, „Lud Słowiański”, t. 4, s. B117-B168.

Kłodnicki Z. (red.)

1995 Komentarze do Polskiego atlasu etnograficznego, t. 2, Budownictwo, Wrocław.

Kondracki J.

2000 Geografia regionalna Polski, Warszawa.

Konopka J.

1874 Gospodarstwo górskie, w: Encyklopedya rolnictwa i wiadomości związek z niém majacych, red. J. Lubomirski, t. 2, Warszawa, s. 812-846. 
Kopernicki I.

1888a Pieśni Górali Bieskidowych z okolic Rabki, „Zbiór Wiadomości do Antropologii Krajowej”, t. 12, cz. 3 [Materyjały etnologiczne], s. 117-226.

1888b Wesele u Górali Bieskidowych z okolic Rabki, „Zbiór Wiadomości do Antropologii Krajowej", t. 12, cz. 3 [Materyjały etnologiczne], s. 230-234.

Kornecki M. (red.)

1984 Materiały słownika terminologicznego budownictwa drewnianego, z. 1/2 [hasła próbne i grupa haseł strop], Kraków.

1988-1989 Materiały słownika terminologicznego budownictwa drewnianego, z. 3/I, 3/II [grupa haseł dach], Kraków.

Kornecki M.

2002 Budownictwo drewniane w krajobrazie kulturowym Karpat i Podkarpacia, „Małopolska: Regiony, Regionalizmy, Małe Ojczyzny”, nr 4, Kraków, s. 153-163.

Krupowicz D.

1965 Rozwój badań nad budownictwem ludowym Karpat Polskich w XIX i XX wieku [praca magisterska napisana pod kier. prof. Mieczysława Gładysza, Katedra Etnografii Słowian UJ].

Kwaśniewski K.

1963 Paleniska i piece w polskim budownictwie ludowym. Studium na podstawie materiałów etnograficznych $z$ drugiej połowy XIX oraz XX wieku, Wrocław.

Leszczycki S.

1932a Badania geograficzne nad osadnictwem w Beskidzie Wyspowym, Kraków.

1932b Osadnictwo Kliszczaków w Beskidzie Wyspowym, „Ziemia”, t. 17, nr 4-5, s. 112 -118 .

1933 Górny zasięg dachów krytych słomą na Podhalu, „Wierchy”, r. 11, s. 208-210.

1990 Osadnictwo Podhala w okresie międzywojennym, Zakopane.

Miśkowiec R.

2015 Z drewna, gliny i cegły - tradycyjne i nowatorskie budownictwo w Skomielnej Białej z XIX i XX wieku, „Zeszyty Rabczańskie”, nr 3-4, s. 295-304.

Moszyński K.

1967 Kultura ludowa Słowian, t. 1, Kultura materialna, Warszawa.

Orzeł T.

2014 Chłopskie budownictwo zagrodowe Raby Wyżnej i Bielanki w drugiej połowie XIX wieku i pierwszej połowie XX wieku, Kraków.

Pokropek M., Pokropek W.

1995 Tradycyjne budownictwo drzewne w Polsce, t. 1, Budownictwo ludowe. Chałupy $i$ ich regionalne zróżnicowanie, Warszawa.

Pol W.

1851 Rzut oka na północne stoki Karpat, Kraków.

Rączka J.W.

1985 Regiony form architektonicznych, „Teka Komisji Urbanistyki i Architektury”, t. 19, s. $121-131$.

1987 Rozważania o metodzie zapisu informacji dotyczacych cech architektury $w$ regionach krajobrazowych, „Teka Komisji Urbanistyki i Architektury”, t. 21, s. 133-137.

Reinfuss R.

1946 Pogranicze krakowsko-góralskie w świetle dawnych i najnowszych badań etnograficznych, „Lud”, t. 36, s. 222-255.

1949 Malowane zręby chałup wiejskich, „Polska Sztuka Ludowa”, t. 3, nr 7/8, s. 200-219. 
1950 Orawski dom z wyżka, „Polska Sztuka Ludowa”, t. 4, nr 1/6, s. 36-55.

1970 Układy rolne i kształty wsi, w: Monografia Powiatu Myślenickiego, red. R. Reinfuss, M. Rydlowa, t. 2, Kultura ludowa, Kraków, s. 11-28.

Rutkowski H. (red.)

2008 Województwo krakowskie w drugiej połowie XVI wieku, cz. 2, Komentarz, indeksy, Warszawa.

Sikorska A., Tworkowski S.

1983 Regionalizm i typizacja jako problemy architektoniczne, „Teka Komisji Urbanistyki i Architektury", t. 15, s. 215-219.

Skoczek A. (red.)

2005 Projekt badawczy rozwoju miejscowości w Karpatach Polskich położonych poza tradycyjnymi obszarami penetracji turystyczno-wypoczynkowej, Kraków.

Syrokomla-Syrokomski M.,

1969 Przemiany wnętrza izby chłopskiej w dorzeczu Górnej Skawy na przestrzeni ostatniego pótwiecza [praca magisterska napisana pod kier. prof. dr. Witolda Dynowskiego, Katedra Etnografii UW].

Świder L.

2014 Jako to downo było, Rdzawka.

Tłoczek I.

1958 Chałupy polskie, Warszawa.

Tylkowa D. (red.)

2000 Podhale: Tradycja we współczesnej kulturze wsi, Kraków.

Udziela S.

1918 Etnograficzne ugrupowanie i rozgraniczenie rodów górali polskich, „Przegląd Geograficzny", t. 1, z. 1-2.

Wójcik J.

1998 Zarys dziejów Sieniawy na tle Gminy Raba Wyżna: Szkic historyczny, Kraków.

Zawiliński R.

1931 Budownictwo orawskie, „Ziemia”, t. 16, nr 8-10, s. 171-174.

\section{Źródła archiwalne}

ANK, Archiwum Narodowe w Krakowie; Kataster galicyjski; Rabka in Galizien Wadowicer Kreis Bezirk Rabka, sygn. 29/280/0/13.1/2597.

WUOZK, Wojewódzki Urząd Ochrony Zabytków w Krakowie; białe karty, zielone karty, karty adresowe dla miejscowości gmin: Spytkowice, Raba Wyżna i Rabka Zdrój.

\section{Źródła internetowe}

GEOPORTAL, http://mapy.geoportal.gov.pl/imap/ (dostęp 29.06.2017).

GOOGLEMAPS, https://www.google.pl/maps/ (dostęp 29.06.2017).

IDO, http://www.kulturowygosciniec.pl/galerie/antropol_rabka/ (dostęp 29.06.2017).

MIIP, http://miip.geomalopolska.pl/imap/ (dostęp 29.06.2017).

RYDET, http://zofiarydet.com/ (dostęp 29.06.2017).

TERYT, http://eteryt.stat.gov.pl (dostęp 29.06.2017). 